\title{
Factors Associated with Bacterial Contamination of Poultry Meat at Butcher Shops in Biskra, Algeria
}

\author{
N. Guergueb* , N. Alloui, A. Ayachi, L. Aoun and I. Chachoua
}

\begin{abstract}
The latest available data indicate that since 2018, poultry has been the most widely consumed meat in the world. However, poultry meat is frequently highly contaminated with microorganisms. Total viable count (TVC), which is also called total aerobic mesophilic bacteria (TAMB), is an indicator of bacterial quality. The aim of this study was to investigate the factors associated with bacterial contamination of poultry meat at butcher shops. The study was carried out from January 2018 to July 2020 and included 10 butcher shops in Biskra (Algeria). Different poultry meat samples $(n=159)$ were purchased from butcher shops, prior to and after the outbreak of COVID-19. Each sample was tested for TAMB and faecal coliforms. In this study, one independent variable was quantitative, which is the contamination of poultry meat by faecal coliforms, and nine variables were categorical: whole carcass packed at the slaughterhouse or cut at butcher shop, sample type: thigh skin, thigh meat, neck skin, liver, turkey escalope, and before or after the outbreak of COVID-19. Descriptive statistics,
\end{abstract}

multiple correspondence analysis (MCA) and multiple linear regression were used to examine if the various factors identified were associated with the bacterial contamination of poultry meat. The average level of contamination of poultry meat by TAMB was: $6.40 \pm 0.81 \log _{10}$ CFU/g. MCA results with graphical representations of qualitative and quantitative variables show the interfactor relationships. The multiple regression model explained $48.6 \%$ of the TAMB variations and estimated TAMB contamination of poultry meat according to the equation: $\mathrm{Y}=0.477$ $\mathrm{X}_{1}+(-0.639) \mathrm{X}_{2}+(-0.557) \mathrm{X}_{3}+(-0.295) \mathrm{X}_{4}$ +5.522; Y (TAMB in $\log _{10}$ CFU/g), $X_{1}$ (faecal coliforms in $\log _{10} \mathrm{CFU} / \mathrm{g}$ ), $\mathrm{X}_{2}$ (Before/after COVID-19), $X_{3}$ (Turkey escalope), $X_{4}$ (Carcass/ cut). Identifying the factors associated with bacterial contamination of poultry meat is necessary to implement effective preventive measures in butcher shops, thus significantly reducing contamination levels and providing customers with high quality poultry meat.

Key words: poultry meat; TVC; APC; MCA; regression model; COVID-19

Nadjah GUERGUEB*, DVM, MSc, Assistant Professor, (Corresponding author, e-mail: g.nadjah@yahoo. fr), Nadir ALLOUI, DVM, PhD, Full Professor, Ammar AYACHI, DVM, PhD, Full Professor, Department of Veterinary Medicine, The University Batna1, Batna, Algeria; Laila AOUN, DVM, PhD, Full Professor, Department of Veterinary Medicine, Chadli Bendjedid University, El Tarf, Algeria; Ilhem CHACHOUA, DVM, PhD, Department of Agricultural Sciences, The University Batna1, Batna, Algeria 


\section{Introduction}

The last data indicate that since 2018, poultry has became the most widely consumed meat worldwide (Faostat, 2020). In Algeria, poultry meat was the primary meat consumed, surpassing sheep and beef between 1980-2012 (Figure 1), with an annual growth rate of $10 \%$ from 1980 to 2005 , though this rate of increase decreased to 0.74 between 2005 2018 (Figure 1).

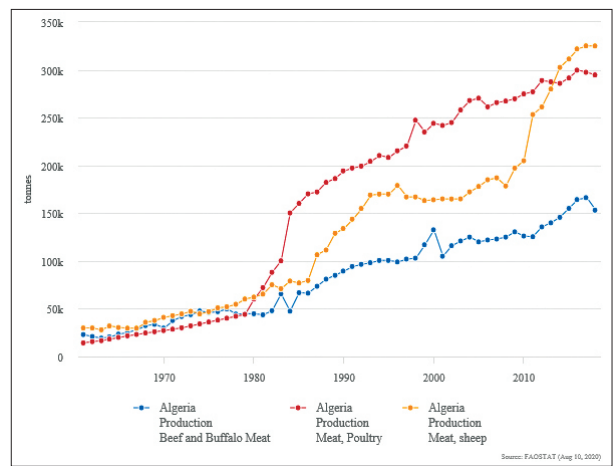

Figure 1. Annual meat consumption in Algeria (1962-2018)

Source: (Faostat, 2020)

As with most meats, raw poultry is frequently highly contaminated with microorganisms (McKee, 2007). The types of microorganisms present on muscle food products and their numbers depend on the sanitary conditions in the environment of origin of the food, the properties and microbiological quality of any added ingredients, the extent of product processing and handling, and the conditions involved in subsequent storage, handling and distribution (Sofos, 1994). One of the most common microbiological tests carried out on foods is the total viable count (TVC), which is also known as the standard plate count or aerobic plate count (APC) (Forsythe and Hayes, 1998), and total aerobic mesophilic bacteria (TAMB). This is a general and extensively applied microbiological indicator of food quality, indicating the adequacy of temperature and sanitation control during processing, transport, and storage, and revealing sources of contamination during production (Herrera, 2001). The microbiology of carcasses and meat of broiler chickens has been extensively studied (Cox et al., 1998), though few studies have investigated factors affecting the bacterial contamination in poultry meat.

The aim of this study was to investigate the factors associated with bacterial contamination of poultry meat at butcher shops.

\section{Materials and Methods}

The study was carried out from January 2018 to July 2020 and included 10 butcher shops in Biskra (Algeria). Different cuts of poultry meat samples $(n=159)$ were purchased from each butcher shop, before and after the outbreak of COVID-19. All samples were subjected to bacteriological analysis.

COVID-19 is an infectious disease caused by the most recently discovered coronavirus. This new virus and disease were unknown prior to the outbreak in Wuhan, China in December 2019. COVID-19 is now a pandemic affecting many countries globally (WHO, 2020).

\section{Bacteriological analyses}

Each sample was tested for total aerobic mesophilic bacteria (TAMB); $\mathrm{TAMB}=\mathrm{TVC}$, and faecal coliforms. TAMB and faecal coliforms were enumerated by creating a 1/10 mother suspension in $0.85 \%$ physiological saline solution, then performing decimal dilutions up to $10^{7}$ dilution. Analyses were carried out in accordance with AFNOR standards (Table 1). 
Table 1. Media and culture conditions for the enumerated bacterial groups

\begin{tabular}{|l|l|l|l|}
\hline Bacterial group & Standard & Culture media & Culture condition \\
\hline TAMB & NFV 8-051 & PCA & $30^{\circ} \mathrm{C}$ during $72 \mathrm{~h}$ \\
\hline Faecal coliforms & NFV 08-60 & VRBL & $44.5^{\circ} \mathrm{C}$ during $48 \mathrm{~h}$ \\
\hline
\end{tabular}

\section{Definition of explanatory variables}

In this study, only one predictor variable was quantitative, i.e. the contamination of poultry meat by faecal coliforms, while nine variables were categorical (Table 2).

Table 2. Definition of explanatory categorical variables included in the analysis of bacterial contamination and percentage of poultry meat sampled for each of the variables

\begin{tabular}{|l|l|l|}
\hline $\begin{array}{l}\text { Definition } \\
\text { of variables }\end{array}$ & Level & $\begin{array}{l}\text { Poultry } \\
\text { meat (\%) }\end{array}$ \\
\hline \multirow{2}{*}{ carcass/cut } & Carcass & 29.94 \\
\cline { 2 - 3 } & cut & 70.06 \\
\hline & thigh skin & 40.12 \\
\hline thigh meat & 28.14 \\
\hline \multirow{2}{*}{ Sample } & neck skin & 12.57 \\
\hline \multirow{2}{*}{$\begin{array}{l}\text { liver } \\
\text { before/after } \\
\text { COVID-19 }\end{array}$} & $\begin{array}{l}\text { Turkey } \\
\text { escalope }\end{array}$ & 8.98 \\
\hline & after COVID-19 & 18.56 \\
\hline
\end{tabular}

\section{Statistical analysis}

Descriptive statistics, multiple correspondence analysis (MCA) and multiple linear regression were used to examine if the various factors examined were associated with the bacterial contamination of poultry meat. Descriptive statistics were used to analyse the data. In addition, microbial counts were transformed to $\log _{10}$ $\mathrm{CFU} / \mathrm{g}$ for statistical analysis. Statistical significance was set at $P$-value $\leq 0.05$ with a 95\% confidence interval (95\%
CI). Multiple correspondence analysis (MCA) was used to show the associations between the bacterial contamination of poultry meat and the factors. Multiple linear regression was used to estimate the coefficients of the linear equation to predict the value of bacterial contamination of poultry meat. SPSS software (Statistical package for social science version 21, IBM/SPSS) was used for descriptive analyses and multiple linear regression. MCA was performed with R software.

\section{Results}

\section{TAMB contamination of poultry meat}

The average level contamination of poultry meat by TAMB was $6.40 \pm 0.81$ $\log _{10} \mathrm{CFU} / \mathrm{g}$.

\section{Factors affecting the TAMB contamination of poultry meat}

The relationship between the contamination of poultry meat by TAMB and the examined factors was analysed. In the first step, a multiple correspondence analysis (MCA) was carried out to identify the hypotheses, whose validity was then tested with the multiple linear regression.

\section{Multiple correspondence analysis (MCA)}

In this section, we study the possible link between the contamination of poultry meat by TAMB and certain risk factors, namely:

- Contamination of poultry meat by faecal coliforms,

- Whole carcass packed at the slaughterhouse or cut at the butcher shop, 


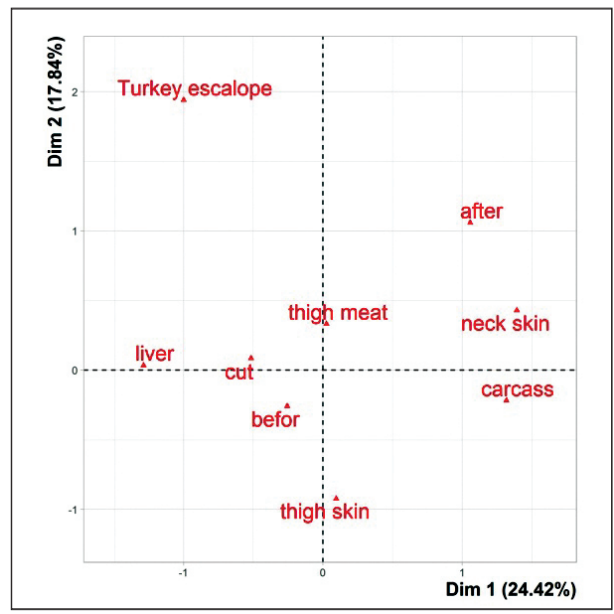

Figure 2. Results of the MCA with graphical representation of qualitative variables for the first (Dim1) and second (Dim 2) dimensions

carcass $=$ whole carcass packed at the slaughterhouse, cut= piece cut at the butcher shop, before=before the appearance of COVID-19, after =after the appearance of COVID-19, thigh skin, thigh meat, liver, Turkey escalope, neck skin.

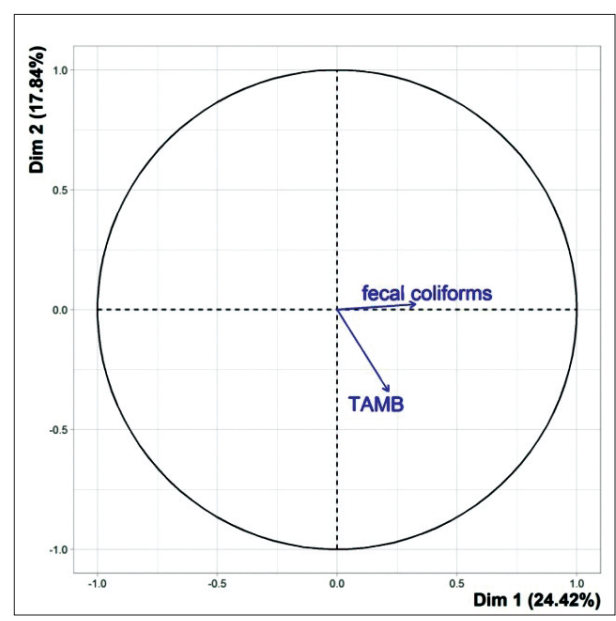

Figure 3. Graphical representation of quantitative variables on the first two dimensions

- Cut (kind) of the sample: thigh skin, thigh meat, neck skin, liver, turkey escalope,

- Before or after the appearance of COVID-19.
Table 3. Summary of the multiple regression model according to the contamination of poultry meat by TAMB

\begin{tabular}{|c|c|c|c|c|}
\hline $\begin{array}{c}\text { Model } \\
1\end{array}$ & $\mathbf{R}$ & $\mathbf{R}^{2}$ & $\begin{array}{c}\mathbf{R}^{2} \\
\text { adjusted }\end{array}$ & $\begin{array}{c}\text { Standard } \\
\text { error }\end{array}$ \\
\hline 1 & 0.697 & 0.486 & 0.461 & 0.57 \\
\hline
\end{tabular}

The first two dimensions explained $42.54 \%$ of the MCA (inertia), indicating that $42.54 \%$ of the total variability of the cloud of individuals is represented in this plane (Figure 2 and Figure 3). Figure 2 shows the distribution of qualitative factors according to the first $(24.42 \%$ of the total variance) and second (17.84\% of the total variance) dimensions, while Figure 3 shows the graphical representation of quantitative factors of the these two dimensions.

From Figure 2 and 3, it is evident that whole carcasses, thigh skins and poultry meat purchased before COVID-19 were most contaminated with TAMB, while turkey escalope was the least contaminated with TAMB. There is a positive correlation between TAMB and faecal contamination of poultry meat.

\section{Multiple linear regression}

A multiple linear regression was carried out to describe and predict the variations in the contamination of poultry meat by TAMB, as associated with the factors studied. Table3 presents a summary of the regression model.

The correlation coefficient was $\mathrm{r}=0.697 \quad(P$-value<0.001): there is a significant correlation between the different risk factors and the contamination of poultry meat by TAMB at butcher shops. The coefficient of determination was $r^{2}=0.486$, i.e. this regression model explains $48.6 \%$ of variations in the contamination of poultry meat by TAMB, while the remaining $51.4 \%$ is explained by other factors. The equation of the regression model can be formulated by using the coefficients of Table 4 . 
Table 4. Summary of the coefficients of the multiple linear regression model according to the contamination of poultry meat by TAMB purchased from butcher shops in Biskra, Algeria during 20182020

\begin{tabular}{|l|c|c|c|c|c|}
\multirow{2}{*}{ Model } & \multicolumn{2}{|c|}{$\begin{array}{c}\text { Unstandardized } \\
\text { coefficients }\end{array}$} & $\begin{array}{c}\text { Standardized } \\
\text { coefficients }\end{array}$ & \multirow{2}{*}{$\mathbf{t}$} & P-value \\
\cline { 2 - 5 } & A & $\begin{array}{c}\text { Standard } \\
\text { error }\end{array}$ & Beta & & \\
\hline (Constant) & 5.522 & 0.352 & & 15.706 & 0.000 \\
\hline Faecal coliforms & 0.477 & 0.054 & 0.602 & $8.803^{*}$ & 0.000 \\
\hline thigh meat & -0.204 & 0.118 & -0.114 & -1.722 & 0.087 \\
\hline neck skin & -0.114 & 0.146 & -0.051 & -0.780 & 0.437 \\
\hline Liver & -0.183 & 0.168 & -0.071 & -1.089 & 0.278 \\
\hline Turkey escalope & -0.557 & 0.163 & -0.228 & $-3.426^{*}$ & 0.001 \\
\hline Carcass/cut & -0.295 & 0.117 & -0.164 & $-2.526^{*}$ & 0.013 \\
\hline Before/after & -0.639 & 0.129 & -0.330 & $-4.969^{*}$ & 0.000 \\
\hline COVID-19 & & & & & \\
\hline
\end{tabular}

*significance level $P$-value $<0.05$

The most influential factors on the contamination of poultry meat by TAMB are:

- Faecal coliforms: the increase of one $\log _{10} \mathrm{CFU} / \mathrm{g}$ of the contamination of poultry meat by faecal coliforms increased the TAMB contamination in poultry meat by $0.477 \log _{10} \mathrm{CFU} / \mathrm{g}$.

- Before/after COVID19: the purchase of poultry meat after COVID-19 decreased the contamination of poultry meat by TAMB by $0.639 \log _{10}$ CFU/g.

- Turkey escalope: this type of meat reduced the contamination of poultry meat by TAMB by 0.557 $\log _{10} \mathrm{CFU} / \mathrm{g}$.

- Carcass/cut: the cut characteristic decreased the contamination of poultry meat by TAMB by 0.295 $\log _{10} \mathrm{CFU} / \mathrm{g}$.

The multiple linear regression model is therefore:

$$
Y=\beta_{1} X_{1}+\beta_{2} X_{2}+\beta_{3} X_{3}+\beta_{4} X_{4}+\beta_{0^{\prime}}
$$

Where: $\mathrm{Y}=\mathrm{TAMB}$ in $\log _{10} \mathrm{CFU} / \mathrm{g}$, $X_{1}=$ faecal coliforms in $\log _{10} \mathrm{CFU} / \mathrm{g}$, $X_{2}=$ Before/after COVID-19, $X_{3}=$ Turkey escalope, $\mathrm{X}_{4}=$ Carcass/cut.

The equation for predicting the contamination of poultry meat by TAMB has the following coefficients: $\beta_{1}=0.477 \pm 0.054$; $\beta_{2}=-0.639 \pm 0.129 ; \quad \beta_{3}=-0.557 \pm 0.163 ; \quad \beta_{4}=$ $-0.295 \pm 0.117 ; \beta_{0}=5.522 \pm 0.352$.

Therefore, the regression model is written as follows:

$$
Y=0.477 X_{1}+(-0.639) X_{2}+(-0.557) X_{3}+
$$
$(-0.295) X_{4}+5.522$ with a standard error of $0.57 \log _{10} \mathrm{CFU} / \mathrm{g}$.

Figure 4 shows the dispersion of the actual and predicted TAMB values contaminating poultry meat according to the prediction equation: $\mathrm{Y}=\mathbf{0 . 4 7 7 \mathrm { X } _ { 1 }}+$ $(-0.639) X_{2}+(-0.557) X_{3}+(-0.295) X_{4}+5.522$ with a standard error of $0.57 \log _{10} \mathrm{CFU} / \mathrm{g}$. 


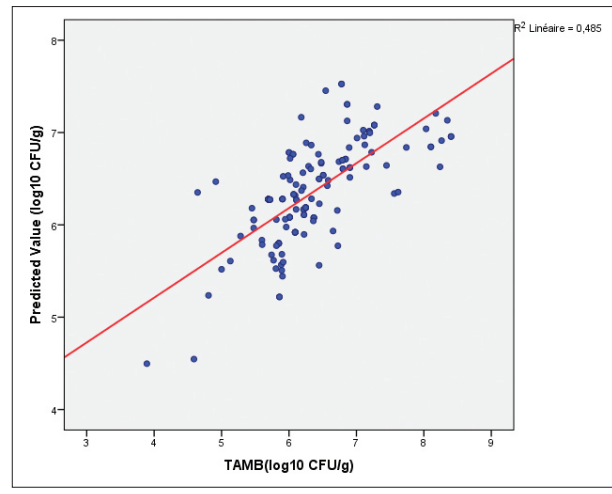

Figure 4. Multiple regression model of the TAMB associated with factors studied according to the prediction equation

\section{Discussion}

The present study was designed to estimate the relationships between the bacterial contamination level of poultry meat and certain factors in butcher shops.

\section{Contamination of poultry meat with TAMB}

Total mesophilic count is an microorganism indicator of general contamination (Da-Silva et al., 2012). In this study, the mean of TAMB (TAMB $=$ TVC) of poultry meat collected from butcher shops $(6.40 \pm 0.81)$ are similar to those reported earlier: $5.8 \log _{10} \mathrm{CFU} / \mathrm{g}$ (Mahato, 2019), the mean TVC of raw chicken collected from markets fell in the range of 5.7-6.4 $\log _{10} \mathrm{CFU} / \mathrm{g}$ (Heetun et al., 2015) and 5.79 and $5.85 \log _{10}$ CFU/g counts of mesophiles in leg and wing samples respectively (Alvarez-Astroga et al., 2002). However, higher results than ours were reported by Bantawa et al. (2018), where $8.22 \pm 0.14 \log _{10}$ CFU /g was the mean of TVC value in chicken. On the other hand, lower levels than ours were reported by Kozačinski et al. (2006), where the mean population of aerobic mesophilic bacteria varied from $3.7 \log _{10}$ CFU/g (breasts with skin), $4.7 \log _{10} \mathrm{CFU} / \mathrm{g}$ (fillets) to $5.4 \log _{10} \mathrm{CFU} / \mathrm{g}$ (retail cut chicken meat).
This variability of microbial load could be attributed to both the site sampled and the sampling method (Grau, 1986). There are, however, other factors and the present study examined several factors that influence the level of bacterial contamination of poultry meats.

\section{Factors affecting the bacterial contamination of poultry meat}

This study used MCA and multiple linear regression to estimate the factors associated with the contamination of poultry meat. MCA allowed for description and visualization of the relationships between TAMB and these factors, as a very useful method to describe and visualize relationships between several variables and categories in survey data (Le Roux and Rouanet, 2010).

Regression linear multiple method was employed to allow prediction and to model the relationship between the bacterial contamination of poultry meat associated with specific factors in butcher shops. Regression analysis is a statistical technique for investigating and modelling the relationship between variables. An important objective of regression analysis is to estimate the unknown parameters in the regression model (Montgomery et al., 2012). The significant factors in this study will be discussed.

\section{Faecal coliforms}

The current study found that there was an increase of $0.477 \log _{10} \mathrm{CFU} / \mathrm{g}$ $(P$-value $<0.001)$ in the contamination of poultry meat by TAMB associated with the increase of every $1 \log _{10} \mathrm{CFU} / \mathrm{g}$ contamination of poultry meat by faecal coliforms (Table 4).

Figure 3 showed that there is a positive correlation between contamination of poultry meat by TAMB and the contamination of poultry meat by faecal coliforms. These findings support the findings of Chipley, (1987) who reported 
a correlation between the level of contamination by coliforms and the total number of bacteria.

\section{Before and after COVID-19}

There was a decrease of $0.639 \log _{10} \mathrm{CFU}$ /g ( $P$-value $<0.001)$ in the contamination of poultry meat by TAMB associated with the purchase of poultry meat after COVID-19 (Table 4). Figure 2 and 3 show a positive correlation was found between before COVID-19 characteristic and the contamination of poultry meat by TAMB.

These results may be explained by the fact that the Algerian government has issued several decrees laying down additional measures to prevent and combat the spread of the Coronavirus (COVID-19). These measures include the obligation to wear a safety mask (Joradp, 2020a), making disinfectant products available to users and customers, in particular hydro-alcoholic gels, and daily cleaning and disinfection of business premises (Joradp, 2020b).

These results corroborate the findings of Jay (2000), who suggested that the microbiota on the hands and outer garments of handlers generally reflect the environment and habits of individuals, and the organisms in question may be those from soils, waters, dust, and other environmental sources. Additional important sources are those that are common in nasal cavities and the mouth and on the skin, and those from the gastrointestinal tract that may enter foods through poor personal hygienic practice. Froning, (1987) reported that the growth of microorganisms can be minimised with the implementation of good quality control practices. Mead, (1995) indicated that essential steps to prevent excessive levels of contamination include prompt washing and chilling of eviscerated birds and effective cleaning and disinfection procedures for equipment and working surfaces at the end of the processing period, prior to the next day's production. Froning, (1987) further suggested that hand-washing facilities adjacent to operators in plants reduce bacterial contamination during cutting and packaging.

\section{Turkey escalope}

There was a decrease of 0.55 $\log _{10} \quad \mathrm{CFU} / \mathrm{g} \quad(P$-value $=0.001)$ in the contamination of poultry meat by TAMB associated with turkey escalope (Table 4). According to Figure 2 and 3, a negative correlation was found between the contamination of poultry meat by TAMB and the characteristic turkey escalope.

A possible explanation for this might be that Turkey escalope, which is a deep part of poultry breast meat, is skinless and therefore less contaminated by bacteria. These results agree with the findings of other studies, in which microbial contamination occurs over the entire outer surface of the processed carcass and in the abdominal cavity (Mead, 2007). Poultry skin supports the growth of the poultry spoilage flora even better than muscle tissue (Jay, 2000).

\section{Carcass/cut}

There was a decrease of 0.295 $\log _{10} \quad \mathrm{CFU} / \mathrm{g} \quad(P$-value $=0.013)$ in the contamination of poultry meat by TAMB associated with cut samples (Table 4). According to Figure 2 and 3, the level of contamination of poultry meat by TAMB is positively correlated with the whole carcass characteristic.

These results could be explained in that in these butcher shops, the cut pieces come from whole carcasses packaged beforehand at slaughterhouses, and the butcher removes and cleans the parts that are too contaminated or that are not well cleaned at the slaughterhouse, finally displaying the cut pieces in refrigerated display cases. In accordance with the present results, previous studies have demonstrated that the removal of surface contaminants introduced during 
slaughter on meat surfaces slows or prevents the growth of contaminants (Niven, 1986). Trimming the skin or outer tissue also reduces the number and types of pathogens on dressed carcasses and finished products (Jay, 2000).

Overall, numerous studies have addressed most of the methods noted above for removing microorganisms from slaughter carcasses, and reductions of TVCs on the order of 1 to $3 \log$ cycles is common (Jay, 2000).

\section{Conclusions}

In this study, we examined factors related to the bacterial contamination of poultry meat, and constructed a multiple regression model to predict TAMB contamination of poultry meat according to the equation:

$$
\begin{aligned}
& Y=0.477 X_{1}+(-0.639) X_{2}+(-0.557) X_{3}+ \\
& (-0.295) X_{4}+5.522
\end{aligned}
$$

Where: $\mathrm{Y}=\mathrm{TAMB}$ in $\log _{10} \mathrm{CFU} / \mathrm{g}$, $\mathrm{X}_{1}=$ faecal coliforms in $\log _{10} \mathrm{CFU} / \mathrm{g}$, $X_{2}=$ before/after COVID-19, $X_{3}=$ Turkey escalope, and $\mathrm{X}_{4}=$ Carcass/cut.

This model explained $48.6 \%$ of the TAMB variations, while the remaining $51.4 \%$ were associated with other factors. Identifying factors associated with bacterial contamination of poultry meat is necessary to create effective preventive measures in butcher shops, thus significantly reducing contamination levels and providing customers with high quality poultry meat.

\section{References}

1. AlvareZ-ASTORGA, M. A., R. CAPITA, C. ALONSO-CALLEJA and B. MORENO (2002): Microbiological quality of retail chicken byproducts in Spain. Meat Sci. 62, 45-50.

2. BANTAWA, K., K. RAI, D. S. LIMBU and H. KHANAL(2018): Foodborne bacterial pathogens in marketed raw meat of Dharan, eastern Nepal. BMC Research Notes 11:618.

3. CHIPLEY, J. R. (1987): Standard and Experimental Methods of Identification and Enumeration. In: Cunningham, F. E. and N. A. Cox, The Microbiology of Poultry Meat Products. Academic press, Inc.

4. COX, N. A., S. M. RUSSELL and J. S. BAILEY (1998): The microbiology of stored poultry. In: Davies, A. and R. Board. The Microbiology of Meat and Poultry (pp. 266-287). Blackie academic \& professional.

5. DA-SILVA, N., M. H. TANIWAKI, V. C. JUNQUEIRA, N.SILVEIRA, M. S. DONASCIMENTO and R. A. R. GOMES (2012): Microbiological Examination Methods of Food and Water: A Laboratory Manual. CRC.

6. FAOSTAT (2020): FAO. Consulted on 10 03, 2020, http://www.fao.org/faostat/en/\#home

7. FORSYTHE, S. J. and P. R. HAYES (1998): Microbiological examining methods. In: Forsythe, S. J. and P. R.Hayes. Food Hygiene, Microbiology and HACCP (pp. 150-202). Springer-Science+Business Media, B.V.

8. FRONING, G. W. (1987): Further-Processed Poultry Meat Products. In: Cunningham, F. E. and N. A. Cox, The Microbiology of Poultry Meat Products (pp. 317-332). Academic press, Inc.

9. GRAU, F. H. (1986): Microbial Ecology of Meat and Poultry. In: Pearson, A. M. and T. R. Dutson, Meat and Poultry Microbiology (pp. 1-47). Macmillan education.

10. HEETUN, I., D. GOBURDHUN and H. NEETOO (2015): Comparative Microbiological Evaluation of Raw Chicken from Markets and Chilled Outlets of Mauritius. J. World's Poult. 5, 10-18.

11. HERRERA, A. G. (2001): Mesophilic Aerobic Microorganisms. In: Spencer, J. F. T., and A. L. R. de-Spencer, Food Microbiology Protocols (pp. 2526). Humana Press Inc.

12. JAY, J. M. (2000): Modern Food Microbiology. Aspen publication.

13. JORADP (2020a): Executive Decree No. 20-127 of May 20, 2020 setting additional measures to prevent and fight against the spread of the Coronavirus (COVID-19). Journal oficiel de la republique algerienne democratique et populair, ( $\left.\mathrm{N}^{\circ} 30\right)$, p. 32.

14. JORADP (2020b): Executive Decree No. 20-159 of June 13, 2020 on the reorganization of home confinement and the measures taken within the framework of the prevention and control system against the spread of Coronavirus (COVID-19), Article 12. Journal officiel de la republique algerienne, $\mathrm{N}^{\circ} 35$, p. 18

15. KOZAČINSKI, L., M. HADŽIOSMANOVIC and N ZDOLEC (2006): Microbiological quality of poultry meat on the Croatian market. Vet. arhiv 76, 305-313.

16. LE ROUX, B. and H. ROUANET (2010): Multiple Correspondence Analysis. Sage.

17. MAHATO, S. (2019): Relationship of Sanitation Parameters with Microbial Diversity and Load in Raw Meat from the Outlets of the Metropolitan City Biratnagar, Nepal. Int. J. Microbiol. 3547072. doi: $10.1155 / 2019 / 3547072$

18. MCKEE, L. (2007): Microbiological and Sensory Properties of Fresh and Frozen Poultry. In: Nollet, L. M. L. Handbook of Meat, Poultry and Seafood Quality (pp. 487-496). Blackwell Publishing.

19. MEAD, G. C. (1995): Hygiene Problems and Control of Process Contamination. In: G. C. Mead. Processing of poultry. Springer-Science and Business Media, B.V.

20. MEAD, G. C. (2007): Sampling methods for poultrymeat products. In: G. C. Mead, Microbiological 
analysis of red meat, poultry and eggs (pp. 148164). Woodhead Publishing Limited.

21. MONTGOMERY, D. C., E. A. PECK and G. G.VINING (2012): Introduction to Linear Regression Analysis.Wiley.

22. NIVEN, C. F. (1986): Perspective on Potentially Fruitful Research Areas. In: Pearson, A. M. and T. R.Dutson, Meat and Poultry Microbiology (pp. 397-410). The AVI Publishing Company Inc \& Macmillan Publishers ltd.
23. SOFOS, J. N. (1994): Microbial growth and its control in meat, poultry. In: Pearson, A.M. and T.R.Dutson. Quality Attributes and their Measurement in Meat, Poultry and Fish Products (pp. 359-403). SpringerScience+Business Media, B.V.

24. WHO (2020): World Health Organisation. Consulté le 08 21, 2020, https://www.who.int/emergencies/ diseases/novel-coronavirus-2019/question-andanswers-hub/q-a-detail/q-a-coronaviruses

\section{Faktori povezani s bakterijskom kontaminacijom mesa peradi u mesnicama u Biskri, Alžir}

Mr. sc. Nadjah GUERGUEB, dr. med. vet., docentica, dr. sc. Nadir ALLOUI, dr. med. vet., redovita profesorica, dr. sc. Ammar AYACHI, dr. med. vet., redoviti profesor, Zavod za veterinarsku medicinu, Univerzitet u Batni1, Batna, Alžir; dr. sc. Laila AOUN, dr. med. vet, redovita profesorica, Zavod za veterinarsku medicinu, Univerizet Chadli Bendjedid, El Tarf, Alžir; dr. sc. Ilhem CHACHOUA, dr. med. vet., Zavod za poljoprivredne znanosti, Univerzitet u Batni1, Batna, Alžir

Najnoviji dostupni podatci pokazuju da je od 2018. godine meso peradi najviše konzumirano meso na svijetu. Međutim, meso peradi često je vrlo kontaminirano mikroorganizmima. Ukupni broj živih mikroorganizama (engl. total viable count; TVC), koji se naziva i "ukupan broj aerobnih mezofilnih bakterija" (engl. total aerobic mesophilic bacteria; TAMB) indikator je bakterijske kvalitete. Cilj ove studije bio je ispitati faktore povezane s bakterijskom kontaminacijom mesa peradi u mesnicama. Studija je provedena od siječnja 2018. do srpnja 2020. i uključivala je 10 mesnica u Biskri (Alžir). Iz svake mesnice kupljene su različite vrste uzoraka mesa peradi $(n=159)$, prije i nakon koronavirusne bolesti (COVID-19). Svaki uzorak ispitan je na TAMB i fekalne koliforme. U ovoj studiji, jedna nezavisna varijabla bila je kvantitativna, a to je kontaminacija mesa peradi fekalnim koliformima, a devet varijabli bilo je kategorijsko: cijeli trup pakiran u klaonici ili rezan u mesnici, vrsta uzorka: koža zabatka, meso zabatka, koža vrata, jetra, pureća šnicla, te prije i nakon pojave COVID-19. Rabljena je opisna (engl. multiple correspondence analysis; MCA) i višestruka linearna regresija za ispitivanje jesu li različiti prepoznati faktori povezani s bakterijskom kontaminacijom mesa peradi. Prosječna razina kontaminacije mesa peradi putem TAMB bila je: $\left(6,40 \pm 0,81 \log _{10} \mathrm{CFU} / \mathrm{g}\right)$. MCA rezultati s grafičkim prikazom kvalitativnih i kvantitativne varijable prikazuju odnos međufaktora. Izrađen je model višestruke regresije što omogućuje objasniti 48,6\% TAMB varijacija i procijeniti TAMB kontaminaciju mesa peradi prema jednadžbi: $Y=0,477 X_{1}+$ $(-0,639) X_{2}+(-0,557) X_{3}+(-0,295) X_{4}+5.522$; $\mathrm{Y}$ (TAMB u $\log _{10} \mathrm{CFU} / \mathrm{g}$ ), $\mathrm{X}_{1}$ (fekalni koliformi u $\log _{10} \mathrm{CFU} / \mathrm{g}$ ), $X_{2}$ (prije/nakon COVID-19), $X_{3}$ (pureća šnicla), $X_{4}$ (trup/komad mesa). Identifikacijski faktori povezani s bakterijskom kontaminacijom mesa peradi potreban je za kreiranje učinkovitih preventivnih mjera $u$ mesnicama da bi se znatno smanjila razina kontaminacije i kupcima osiguralo meso peradi izuzetne kvalitete.

Ključne riječi: meso peradi, TVC, APC (broj aerobnih kolonija), MCA, model regresije, COVID-19 